\title{
The Potential of a Brown Microalga Cultivated in High Salt Medium for the Production of High-Value Compounds
}

\author{
Saoussan Boukhris, ${ }^{1}$ Khaled Athmouni, ${ }^{2}$ Ibtissem Hamza-Mnif, ${ }^{1}$ Rayda Siala-Elleuch, \\ Habib Ayadi, ${ }^{2}$ Moncef Nasri, ${ }^{1}$ and Alya Sellami-Kamoun ${ }^{1}$ \\ ${ }^{1}$ Laboratory of Enzyme Engineering and Microbiology, University of Sfax, National Engineering School of Sfax, \\ BP 1173, 3000 Sfax, Tunisia \\ ${ }^{2}$ Laboratory of Biodiversity and Aquatic Ecosystems, Ecology and Planktonology, Department of Life Sciences, Sfax University, \\ Soukra Km 3.5, BP 1171, 3000 Sfax, Tunisia
}

Correspondence should be addressed to Alya Sellami-Kamoun; kamoun_alya@tunet.tn

Received 9 February 2017; Accepted 27 April 2017; Published 22 May 2017

Academic Editor: María M. Yust

Copyright (C) 2017 Saoussan Boukhris et al. This is an open access article distributed under the Creative Commons Attribution License, which permits unrestricted use, distribution, and reproduction in any medium, provided the original work is properly cited.

\begin{abstract}
Amphora sp. was isolated from the Sfax Solar Saltern and cultivated under hypersaline conditions. It contains moderate rates of proteins, lipids, sugars, and minerals and a prominent content of bioactive compounds: polyphenols, chlorophyll a, carotenoids, and fatty acids. The analysis of fatty acids with GC/MS showed that the C16 series accounted for about 75\% of Amphora sp. lipids. Saturated fatty acids whose palmitic acid was the most important (27.41\%) represented $41.31 \%$. Amphora sp. was found to be rich in monounsaturated fatty acids with dominance of palmitoleic acid. It also contains a significant percentage of polyunsaturated fatty acids with a high amount of eicosapentaenoic acid (2.36\%). Among the various solvents used, ethanol at $80 \%$ extracted the highest amounts of phenols and flavonoids that were $38.27 \mathrm{mg}$ gallic acid equivalent and $17.69 \mathrm{mg}$ catechin equivalent $\mathrm{g}^{-1}$ of dried extract, respectively. Using various in vitro assays including DPPH and ABTS radicals methods, reducing power assay, and $\beta$-carotene bleaching assay, the $80 \%$ ethanolic extract showed high antioxidant activity. A strong antibacterial activity was checked against Gram-positive bacteria (Staphylococcus aureus and Micrococcus luteus) and Gram-negative bacteria (Klebsiella pneumoniae and Salmonella enterica). These results are in favor of Amphora sp. valorization in aquaculture and food and pharmaceutical industries.
\end{abstract}

\section{Introduction}

Microalgae are considered as an important source of bioactive compounds with a wide range of applications and commercial use. They produce proteins, lipids, vitamins, pigments, and other molecules exploited for health, for food and feed additives, and for energy production. Due to their wide diversity and high storage capacity for lipids, particularly eicosapentaenoic acid (EPA) and amino acids, microalgae have pharmaceutical and cosmetic applications [1, 2]. Furthermore, the protective effects of natural antioxidants, against chemically induced oxidative damage, have been paid attention nowadays, especially when the generation of free radicals is involved. Benthic diatoms have become good sources of natural antioxidants, as revealed by a number of studies [3-6]. Moreover, microalgae represent a large and underexplored resource of antimicrobial compounds $[7,8]$. Potentially, microalgal extracts are already being tested as additives for food and feed formulations, in an attempt to replace the currently used synthetic antimicrobial compounds, including subtherapeutical doses of antibiotics employed as a prophylactic measure in animal breeding [9]. Microalgae are ubiquitously distributed throughout the biosphere, where they have been adapted to survival under a large spectrum of environmental stresses, such as heat, cold, anaerobiosis, salinity, photooxidation, osmotic pressure, and exposure to ultraviolet radiation [10]. Hence, they may grow essentially under most of the environmental conditions available, ranging from freshwater to extreme salinity. They possess the extra advantage of substantial metabolic plasticity, 
dependent on their physiological state. Likewise, their secondary metabolism can easily be triggered by most forms of externally applied stress [7].

Among the large variety of microalgae, Cyanophyceae, Chlorophyceae, Bacillariophyceae (diatoms), and Chrysophyceae are the most studied for biodiesel production [11]. It is estimated that diatoms produce about $25 \%$ of the global primary biomass [12]. In the Sfax Solar Saltern, Bacillariophyceae dominated with Dinophyceae in the least salty ponds but they are rarely abundant in hypersaline environments [13].

Unlike the universal macromolecules of primary metabolism (e.g., monosaccharides, polysaccharides, amino acids, proteins, and lipids), which are commonly present in all organisms, secondary metabolites have a far more limited distribution in nature. They are not necessarily produced under all conditions and can only be found in specific organisms or a group of organisms. The organism can produce these compounds either to protect itself within its own living ecosystem or to play a basic role in its everyday existence. This reveals bioactive molecules in unrelated biological systems [14]. The medicinal and pharmacological actions are often dependent on the presence of bioactive compounds called secondary metabolites [15]. The growth of algae is relatively rapid, and it is possible to control the production of their bioactive compounds such as polyphenols and pigments by modifying culture conditions [10].

In the present work, Amphora sp. (Bacillariophyceae) was cultivated in a hypersaline medium and the physicochemical properties, fatty acids profile, bioactive compounds, and some biological activities were determined.

\section{Materials and Methods}

2.1. Microalga. Amphora sp. is a Bacillariophyceae that was isolated via micromanipulation and serial dilution from a water sample collected in the pond C4-1 of the Sfax Solar Saltern with average salinity of 107 p.s.u. (practical salinity unit). The Sfax Solar Saltern is located in the central eastern cost of Tunisia, at about $34^{\circ} 39^{\prime} \mathrm{N}$ and $10^{\circ} 42^{\prime} \mathrm{E}$. The ponds are shallow (20-70 cm depth) and have various salinities ranging from 40 to 400 p.s.u. [16]. They are connected by pipes and channels along a $12 \mathrm{~km}$ section of sea cost.

2.2. Culture Conditions. The microalga was cultivated in batch in autoclaved artificial seawater, which was enriched with $\mathrm{F} / 2$ nutrient medium, sodium silicate $\left(\mathrm{Na}_{2} \mathrm{SiO}_{3}\right)$, and trace metals solution $[17,18]$. Cultures were conducted for 15 days at the salinity of 100 p.s.u., $25^{\circ} \mathrm{C}$, light : dark (L:D) cycle of $(16 \mathrm{~h}: 8 \mathrm{~h})$, and cool white fluorescent light intensity of $60 \mu$ moles photons $\mathrm{m}^{-2} \mathrm{~s}^{-1}$. The biomass was separated from the culture media by centrifugation $(4500 \times \mathrm{g}, 10 \mathrm{~min})$, and the pellet was washed with distilled water and centrifuged again at $4500 \times \mathrm{g}$ for $10 \mathrm{~min}$ (the washing was repeated two times). The pellet was freeze-dried and stored at $-70^{\circ} \mathrm{C}$.

2.3. Determination of Dry Matter, Ash, Proteins, Lipids, and Total Sugars. The dry matter and ash content were determined according to the AOAC standard methods [19].
Total nitrogen contents of Amphora sp. crude and undigested protein substrates were determined using the Kjeldahl method according to the AOAC method number 984.13 [19] with equipment of BÛCHI Digestion Unit K-424 (Switzerland). Crude proteins were estimated by multiplying the total nitrogen content by the factor of 6.25 .

Lipids content was determined gravimetrically after the Soxhlet extraction of dried samples with hexane for 2 hours using Nahita Model 655 (Navarra, Spain).

As regards sugars, they were estimated by phenol-sulfuric acid method [20] using glucose as a standard.

\subsection{Determination of Pigments Content: Chlorophylls and} Carotenoids. Pigments were determined according to the method described by Lichtenthaler [21]. Two milliliters of culture was centrifuged at $5500 \times \mathrm{g}$ for $5 \mathrm{~min}$, and the supernatant was discarded and the pellet was mixed with $99.9 \%$ methanol and incubated in the dark for 24 hours at $45^{\circ} \mathrm{C}$. After incubation, pigments content was determined measuring absorbances at 470, 652.4, and $665.2 \mathrm{~nm}$, which were corrected for turbidity by subtracting absorbance at $750 \mathrm{~nm}$.

2.5. Determination of Mineral Content. The analysis of sodium, potassium, calcium, magnesium, iron, copper, and zinc contents in Amphora sp. was carried out using the inductively coupled plasma optical emission spectrophotometer (ICP-OES) Model 4300 DV, PerkinElmer (Shelton, CT, USA), according to the method of AOAC 1999 [22]. Measurements were performed in triplicate and the results were the average of three values.

2.6. Determination of Fatty Acids Profile by GC-MS. Fatty acids methyl esters (FAME) were prepared by basic transesterification protocol. The extracted lipids were collected in $10 \mathrm{~mL}$ heptane and introduced into a $50 \mathrm{~mL}$ flask. A volume of $10 \mathrm{~mL}$ of $\mathrm{KOH}$ solution $\left(11 \mathrm{~g} \mathrm{~L}^{-1}\right)$ in methanol was added with a few antibumping beads. The mixture was boiled under reflux condenser for $10 \mathrm{~min}$. Then, $5 \mathrm{~mL}$ of boron trifluoride $\left(\mathrm{BF}_{3}\right)$, methanol complex $\left(150 \mathrm{~g} \mathrm{~L}^{-1}\right)$ was introduced through the condenser by a graduated syringe, and the mixture was boiled for $2 \mathrm{~min}$. The mixture was cooled under room temperature and 15 to $20 \mathrm{~mL}$ of saturated sodium sulfate solution was added and shaken well. Furthermore, this solution was added until the liquid level reached the neck of the flask. After the phase separation, the upper layer (nheptane) was collected by a Pasteur pipette and evaporated under nitrogen flow. The FAME were redissolved in $500 \mu \mathrm{L}$ hexane for GC-MS analysis.

The analysis of FAME was performed with a 6890 GC/5973 MSD GC/MS system from Agilent Technologies, equipped with an HP-INNO Wax Polyethylene Glycol capillary column (30 m length; $250 \mu \mathrm{m}$ diameter; $0.25 \mu \mathrm{m}$ film thickness). Helium was used as a gas carrier with a flow rate through the column of $1 \mathrm{~mL} / \mathrm{min}$. Column temperature was held initially for $1 \mathrm{~min}$ at $200^{\circ} \mathrm{C}$ and increased to $250^{\circ} \mathrm{C}$ at $10^{\circ} \mathrm{C} \mathrm{min}^{-1}$ and was then held at $250^{\circ} \mathrm{C}$ for $15 \mathrm{~min}$. The injector was kept at $260^{\circ} \mathrm{C}$ using a splitless mode, and then a sample of $1 \mu \mathrm{L}$ was injected. The ion source temperature 
was set at $230^{\circ} \mathrm{C}$. The mass spectra were obtained in full scan mode MS, and scan range was $(\mathrm{m} / \mathrm{z})$ : 50-600 atomic mass units (AMU) under electron impact (EI) ionization $(70 \mathrm{eV})$. Data were exploited using the National Institute of Standards and Technology (NIST) Mass Spectral Search Program (version 2.0g).

2.7. Determination of the Total Phenolic Content. The total phenols content in microalga was determined by the Folin-Ciocalteu method [23]. Briefly, $0.2 \mathrm{~mL}$ of extract was mixed with $1 \mathrm{~mL}$ of Folin-Ciocalteu reagent (diluted 1:10, $\mathrm{v} / \mathrm{v}$ ) followed by the addition of $0.8 \mathrm{~mL}$ of sodium carbonate $(7.5 \%, \mathrm{w} / \mathrm{v})$. After incubation in the dark, the absorbance was measured at $760 \mathrm{~nm}$. The total phenolic content of algal extract was expressed as $\mathrm{mg}$ of gallic acid equivalent per $\mathrm{g}$ of dry extract (mg GAE g ${ }^{-1}$ extract) using a calibration curve with gallic acid. All samples were analyzed in triplicate.

2.8. Determination of the Total Flavonoid Content. The total flavonoid content was determined according to the modified method of Zhishen et al. [24]. Briefly, $0.4 \mathrm{~mL}$ of the extract was mixed with $120 \mu \mathrm{L}$ of $5 \%$ sodium nitrite and $120 \mu \mathrm{L}$ of $10 \%$ aluminum chloride followed by the addition of $0.8 \mathrm{~mL}$ of $1 \mathrm{M}$ sodium hydroxide. After the incubation of reaction mixture at room temperature for $6 \mathrm{~min}$, absorbance was measured at $510 \mathrm{~nm}$. The total flavonoids content in the extract was expressed in terms of catechin equivalent $\left(\mathrm{mgg}^{-1}\right.$ of dry extract). All samples were analyzed in triplicate.

2.9. Extraction of Antioxidants. The extracts from the biomass samples were obtained by two solid-liquid extraction procedures inspired from the method of Goiris et al. [25]. In a first step, both apolar and polar compounds were extracted by $80 \%$ ethanol. For this, $2 \mathrm{~g}$ of freeze-dried biomass was ground using a pestle and mortar and extracted under agitation in the dark with $20 \mathrm{~mL}$ ethanol/water $(4 / 1 \mathrm{v} / \mathrm{v})$ mixture at $50^{\circ} \mathrm{C}$ for 1 hour. After centrifugation $(4500 \times \mathrm{g}, 10 \mathrm{~min})$, the pellet was resuspended in $2 \mathrm{~mL}$ of the ethanol/water mixture and extracted for a second time with maceration. The two extracts were pooled and stored at $-20^{\circ} \mathrm{C}$ prior to analysis. The second procedure aimed to separate polar from apolar compounds after sequential extraction in solvents with increasing polarity: hexane, ethyl acetate, and water. Freezedried biomass $(2 \mathrm{~g})$ was ground in a mortar and extracted with $20 \mathrm{~mL}$ of hexane for 1 hour at $50^{\circ} \mathrm{C}$. After centrifugation, the pellet was resuspended in hexane and extracted for a second time, and both extracts were combined. The biomass pellet was subsequently extracted twice with $2 \times 20 \mathrm{~mL}$ ethyl acetate using the same procedure and finally with $2 \times 20 \mathrm{~mL}$ of water at $50^{\circ} \mathrm{C}$ for 1 hour. All extracts were concentrated under reduced pressure by a rotary evaporator to a dry condensed residue. The dried samples were weighed and then stored at $-20^{\circ} \mathrm{C}$ prior to analysis.

2.10. Antioxidant Property. Four in vitro assays were used to evaluate the antioxidant property of the $80 \%$ ethanolic extract of Amphora sp.
2.10.1. 2,2-Diphenylpicrylhydrazyl (DPPH) Free Radical Scavenging Assay. Free radicals scavenging activity was assessed according to Blois [26] with some modifications: $1 \mathrm{~mL}$ of the extract at different concentrations $\left(0.06-1 \mathrm{mg} \mathrm{mL}^{-1}\right)$ was mixed with $1 \mathrm{~mL}$ of $0.1 \mathrm{mM} \mathrm{DPPH}$ in ethanol and $450 \mu \mathrm{L}$ of $50 \mathrm{mM}$ Tris- $\mathrm{HCl}$ buffer ( $\mathrm{pH}$ 7.4). The solution was incubated at $37^{\circ} \mathrm{C}$ for $30 \mathrm{~min}$, and the reduction of $\mathrm{DPPH}$ free radicals was evaluated by reading the absorbance at $517 \mathrm{~nm}$. The DPPH scavenging activity is given as percentage and calculated according to the following equation:

$$
\% \text { DPPH scavenging }=\left[\frac{\left(A_{\text {control }}-A_{\text {test }}\right)}{A_{\text {control }}}\right] \times 100,
$$

where $A_{\text {control }}$ is the absorbance of the reaction medium and $A_{\text {test }}$ is the absorbance of the reaction test containing the extract. The antioxidant activity of each extract was expressed as $\mathrm{IC}_{50}$, defined as the concentration of extract required to cause a 50\% decrease in initial DPPH concentration. Butylated hydroxytoluene (BHT) was used as positive control, and each sample was analyzed three times.

2.10.2. ABTS Radical Scavenging Activity. The Trolox equivalent antioxidant capacity (TEAC) assay, measuring the reduction of the 2,2-azinobis-(3-ethylbenzothiazoline-6-sulfonic acid) ABTS radical cation by antioxidants, was derived from the method of Katalinic et al. [27] with minor modifications. Briefly, ABTS radical cation (ABTS-+) was produced by reacting ABTS stock solution with $2.45 \mathrm{mM}$ potassium persulfate, allowing the mixture to stand in the dark at room temperature for 12-16 hours before use. ABTS.+ solution was diluted with saline phosphate buffer (PBS, $\mathrm{pH}$ 7.4) to absorbance of $0.70( \pm 0.02)$ at $734 \mathrm{~nm}$. After the addition of $2 \mathrm{~mL}$ of diluted ABTS- + solution to $100 \mu \mathrm{L}$ of each extract, or Trolox standard, the reaction mixture was incubated for $30 \mathrm{~min}$ in a glass spectrophotometer cell at $30^{\circ} \mathrm{C}$. The decrease in absorbance was recorded at $734 \mathrm{~nm}$. Measurements were performed in triplicate. Radical scavenging activity was calculated using the formula below:

$$
\% \text { Inhibition }=\left[\frac{\left(A_{\text {control }}-A_{\text {test }}\right)}{A_{\text {control }}}\right] \times 100,
$$

where $A_{\text {control }}$ is the absorbance of the reaction medium and $A_{\text {test }}$ is the absorbance of the reaction medium with the extract. Each sample was analyzed three times.

2.10.3. Ferric Reducing Antioxidant Power (FRAP). The reducing power of the extract was determined according to the method described by Yildirim et al. [28]. Briefly, $0.5 \mathrm{~mL}$ of $80 \%$ ethanolic extract solution at various concentrations (0.1-0.5 $\left.\mathrm{mg} \mathrm{mL}^{-1}\right)$ was mixed with $1.25 \mathrm{~mL}$ of $0.2 \mathrm{M}$ phosphate buffer $(\mathrm{pH} 6.6)$ and $1.25 \mathrm{~mL}$ of $1 \%(\mathrm{w} / \mathrm{v})$ potassium ferricyanide $\mathrm{K}_{3}\left[\mathrm{Fe}(\mathrm{CN})_{6}\right]$. The mixture was incubated at $50^{\circ} \mathrm{C}$ for $20 \mathrm{~min}$, and then $1.25 \mathrm{~mL}$ of $10 \%(\mathrm{w} / \mathrm{v})$ trichloroacetic acid was added to the mixture which was then centrifuged at $3500 \times \mathrm{g}$ for $10 \mathrm{~min}$. The supernatant $(1.25 \mathrm{~mL})$ was mixed with $1.25 \mathrm{~mL}$ distilled water and $0.25 \mathrm{~mL}$ of $0.1 \% \mathrm{FeCl}_{3}(\mathrm{w} / \mathrm{v})$. The absorbance was measured at $700 \mathrm{~nm}$. Ascorbic acid was used as a reference. The increase of the absorbance in the 
reaction indicates the increase of the iron reduction. The values presented are the mean of triplicate analysis.

2.10.4. $\beta$-Carotene-Linoleic Acid Assay. The ability of the extract to prevent the bleaching of $\beta$-carotene was assessed as described by Koleva et al. [29]. A stock solution of $\beta$ carotene/linoleic acid mixture was prepared by dissolving $0.5 \mathrm{mg}$ of $\beta$-carotene in $1 \mathrm{~mL}$ of chloroform, $25 \mu \mathrm{L}$ of linoleic acid, and $200 \mu \mathrm{L}$ of Tween 80 . The chloroform was completely evaporated under vacuum in a rotary evaporator at $40^{\circ} \mathrm{C}$, and then $100 \mathrm{~mL}$ of distilled water was added and the resulting mixture was vigorously stirred. The emulsion obtained was freshly prepared before each experiment. Aliquots $(2.5 \mathrm{~mL})$ of the $\beta$-carotene/linoleic acid emulsion were transferred to test tubes containing $0.1 \mathrm{~mL}$ of extract at different concentrations (0.1-0.5 $\left.\mathrm{mg} \mathrm{mL}^{-1}\right)$. Following incubation for $2 \mathrm{~h}$ at $50^{\circ} \mathrm{C}$, the absorbance of each test was measured at $470 \mathrm{~nm}$. Vitamin C was used as a positive standard. The control tube contained no sample. Antioxidant activity in $\beta$-carotene bleaching model expressed as percentage was calculated with the following equation:

$$
\begin{gathered}
\beta \text {-carotene bleaching inhibition (\%) } \\
\quad=\left[1-\frac{A_{0}-A_{t}}{A^{\prime}{ }_{0}-A^{\prime}{ }_{t}}\right] \times 100,
\end{gathered}
$$

where $A_{0}$ and $A^{\prime}{ }_{0}$ are the absorbance of the sample and the control, respectively, measured at time zero and $A_{t}$ and $A^{\prime}{ }_{t}$ are the absorbance of the sample and the control, respectively, measured after 2 hours. Tests were carried out in triplicate.

2.11. Antibacterial Assays. The operative pathogens were Gram-positive (Bacillus cereus (ATCC11778), Bacillus subtilis (JN934392), Micrococcus luteus (ATCC4698), and Staphylococcus aureus (ATCC6538)) and Gram-negative (Klebsiella pneumoniae (ATCC13883), Salmonella enterica (ATCC43972)) bacteria. The antimicrobial activity of $80 \%$ ethanolic extract was evaluated using agar well diffusion method. The wells were then filled with $60 \mu \mathrm{L}$ of the extract at $20 \mathrm{mg} / \mathrm{mL}$ in 5\% DMSO and 5\% DMSO was used as negative control. Besides, plates were incubated for 24 hours at $37 \pm$ $1^{\circ} \mathrm{C}$ for bacterial strains. Then, the diameters of inhibition zones (IZD) were measured.

2.12. Statistical Analysis. The data for biological and biochemical parameters are expressed as mean \pm SD. Tests were carried out in triplicate. The $\mathrm{IC}_{50}$ values were calculated by Probit Analysis with a reliability interval of $95 \%$.

\section{Results and Discussion}

3.1. Physicochemical Characterization of Amphora sp. Some physicochemical characteristics of Amphora sp. are presented in Table 1. The obtained results have shown that the biomass of Amphora sp. contains moderate amounts of lipids, proteins, carbohydrates, ashes, and minerals and an important percentage of chlorophyll a and carotenoids. The dry matter content of $7 \%$ is close to that found for other strains: $8 \%$

\begin{tabular}{|c|c|}
\hline Component & Amphora sp. \\
\hline Dry matter (\% FW) & $7 \pm 0.45$ \\
\hline Proteins (\% DW) & $27.62 \pm 0.3$ \\
\hline Lipids (\% DW) & $11.14 \pm 0.19$ \\
\hline Total sugars (\% DW) & $12.60 \pm 0.76$ \\
\hline Ashes (\% DW) & $37.78 \pm 0.43$ \\
\hline Chlorophyll a (\% DW) & $4.945 \pm 0.2$ \\
\hline Chlorophyll b (\% DW) & $0.666 \pm 0.05$ \\
\hline Carotenoids (\% DW) & $1.083 \pm 0.05$ \\
\hline Sodium $\left(\mathrm{g} \mathrm{Kg}^{-1} \mathrm{DW}\right)$ & $1.125 \pm 0.2$ \\
\hline Potassium $\left(\mathrm{g} \mathrm{Kg}^{-1} \mathrm{DW}\right)$ & $0.485 \pm 0.05$ \\
\hline Calcium $\left(\mathrm{g} \mathrm{Kg}^{-1} \mathrm{DW}\right)$ & $0.584 \pm 0.05$ \\
\hline Magnesium $\left(\mathrm{g} \mathrm{Kg}^{-1} \mathrm{DW}\right)$ & $0.747 \pm 0.1$ \\
\hline Iron $\left(\mathrm{g} \mathrm{Kg}^{-1} \mathrm{DW}\right)$ & $0.016 \pm 0.002$ \\
\hline Copper $\left(\mathrm{g} \mathrm{Kg}^{-1} \mathrm{DW}\right)$ & $0.008 \pm 0.001$ \\
\hline Zinc $\left(\mathrm{g} \mathrm{Kg}^{-1} \mathrm{DW}\right)$ & $0.008 \pm 0.001$ \\
\hline
\end{tabular}

TABLE 1: Physicochemical characteristics of Amphora sp.

Data are expressed as mean \pm standard deviation of triplicates. FW: fresh weight; DW: dry weight.

for Amphora sp. CTM 20023 [30] and 5.9\% for Amphora coffeaformis [31]. However, the lipids content of Amphora sp. of $11.14 \%$ DW was relatively lower than the values published for other strains of Amphora [32], and it was higher than that of Amphora coffeaformis (6.9\% DW) [31]. A study on eight marine species of diatoms revealed various lipid contents ranging from 2.4 to $21.3 \%$ [33].

The proteins level for Amphora sp. (27.62\%) was lower than that found for other strains of Amphora; 54\% for CTM 20023 [30] and 30-40\% for Amphora sp. [32]. Indeed, the proteins level was in agreement with the published values range of $12-42 \%$ for some microalgae [34] and higher than the contents found for Amphora coffeaformis [31].

The total sugars content of Amphora sp. was $12.60 \% \mathrm{DW}$, which is consistent with that of some microalgae (5-23\% DW) [34]. Nevertheless, Amphora coffeaformis and some diatoms contain a high amount of sugars in the range of $13.5-16.4 \%$ [31].

With respect to the ash content of Amphora sp. $(37.78 \%$ DW), it is in line with that found for another Amphora strain $(30 \% \mathrm{DW})$ cultivated at salinity ranging between 15 and 35 p.s.u. [32]. Ash content exceeds 50\% (55.8 to 67.9\%) of the dry weight for some diatoms [31]. Amphora sp. has moderate amounts of sodium, potassium, calcium, and magnesium.

Moreover, Amphora sp. was found to be rich in chlorophyll, mainly chlorophyll a, and carotenoids. In fact, its chlorophyll content reached almost $5 \%$ of the dry matter, which is in agreement with other research works [30]. Furthermore, the carotenoids content was prominent $(1.083 \%$ DW). Bacillariophyceae exhibited high levels of carotenoids, namely, $\beta$-carotene and xanthophylls, thus indicating a powerful antioxidant activity [35].

3.2. Fatty Acids Composition of Amphora sp. In salinity of 100 p.s.u., on F/2 medium, the fatty acids profile of Amphora sp. was composed of saturated, monounsaturated, 
TABLE 2: Fatty acids composition of Amphora sp. (\% of total fatty acids).

\begin{tabular}{lc}
\hline Fatty acids & Amphora sp. \\
\hline C14:0 & $3.623 \pm 0.3$ \\
C15:0 & $3.418 \pm 0.3$ \\
C16:0 & $27.427 \pm 0.5$ \\
C17:0 & $1.664 \pm 0.4$ \\
C18:0 & $1.974 \pm 0.3$ \\
C20:0 & $0.734 \pm 0.2$ \\
C24:0 & $2.468 \pm 0.2$ \\
\hline$\sum$ SFA & $\mathbf{4 1 . 3 0 8} \pm \mathbf{0 . 8}$ \\
\hline C14:1 & $3.386 \pm 0.3$ \\
C16:1 & $45.089 \pm 0.8$ \\
C17:1 & $0.521 \pm 0.1$ \\
C18:1 & $3.658 \pm 0.3$ \\
\hline$\sum$ MUFA & $\mathbf{5 2 . 6 5 4} \pm \mathbf{1 . 2}$ \\
\hline C16:2 & $1.603 \pm 0.2$ \\
C16:3 & $0.924 \pm 0.3$ \\
C18:2 & $0.432 \pm 0.1$ \\
C20:4 & $0.712 \pm 0.2$ \\
C20:5 & $2.367 \pm 0.3$ \\
\hline$\sum$ PUFA & $\mathbf{6 . 0 3 8} \pm \mathbf{0 . 5}$ \\
\hline
\end{tabular}

$\sum$ SFA: total saturated fatty acids; $\sum$ MUFA: total monounsaturated fatty acids; $\sum$ PUFA: total polyunsaturated fatty acids.

and polyunsaturated fatty acids (SFA, MUFA, and PUFA), respectively (Table 2). The C16 fatty acids series (C16:0, C16:1, $\mathrm{C} 16: 2$, and $\mathrm{C} 16: 3)$ represented more than $75 \%$. Moreover, palmitic acid (C16:0) and palmitoleic acid (C16:1) accounted together for more than $72.51 \%$ of fatty acids. SFA were present at a high level, $41.31 \%$, with $27.41 \%$ of palmitic acid. Hence, Amphora sp. could be a suitable producer of SFA, which are easily convertible to biodiesel [36]. Amphora sp. is rich in MUFA with the dominance of palmitoleic acid (45.09\%) and contains an important percentage of PUFA (6.03\%). High levels of palmitoleic acid and other bioactive fatty acids were also detected in the fusiform morphotype of the Bacillariophyceae Phaeodactylum tricornutum [37]. Eicosapentaenoic acid C20:5 (EPA) was produced in a noticeable level (2.367\%). Indeed, it is known that EPA is an important PUFA for health protection from many pathologies, including cardiovascular diseases [38] and cancer [39].

3.3. Phytochemical Composition. The total phenols and flavonoids contents of Amphora sp. extracts are summarized in Table 3. The $80 \%$ ethanolic extract of this Bacillariophyceae showed the highest phenols and flavonoids contents, $38.27 \pm 2.21 \mathrm{mg} \mathrm{GAE} \mathrm{g}^{-1}$ extract and $17.69 \pm 0.70 \mathrm{mg} \mathrm{CE} \mathrm{g}^{-1}$ extract, respectively, compared to the extracts obtained by ethyl acetate, hexane, and water. The phenolic content of ethanol extracts of some Moroccan marine microalgae was found to range from 8.2 to $32 \mathrm{mg} \mathrm{GAE} \mathrm{g}^{-1}$ extract [40]. The authors noted that the highest phenolic content was found in the extract of Nannochloropsis gaditana with $32 \mathrm{mg} \mathrm{GAE} \mathrm{g}^{-1}$ extract. The extracts of Dunaliella sp., Phaeodactylum tricornutum, and Navicula sp. also contained high phenolic content of more than $15 \mathrm{mg} \mathrm{GAE} \mathrm{g}^{-1}$ extract [40].
The flavonoid content in the $80 \%$ ethanolic extract of Amphora sp. was $3.22 \mathrm{mg} \mathrm{CE} \mathrm{g}^{-1} \mathrm{DW}$, which is sixfold higher than that found for Amphora CTM 20023 [30].

The high levels of polyphenols and flavonoids in the Amphora sp. 80\% ethanolic extract may be due to the culture conditions under the high salinity of 100 p.s.u. and the extraction conditions.

3.4. Antioxidant Property of Amphora sp. Due to its highest content of phenols and flavonoids, the $80 \%$ ethanolic extract was used to check antioxidant activity through four in vitro assays: the DPPH and ABTS radical scavenging capacities, the ferric reducing antioxidant power, and the $\beta$-carotene bleaching inhibition tests, using different concentrations of the extract. The inhibition percentages of the radicals DPPH and ABTS by the extract and standards (Trolox and BHT) were found to be concentration-dependent (0.065 to $1 \mathrm{mg} \mathrm{mL}^{-1}$ for DPPH test and 0.5 to $4 \mathrm{mg} \mathrm{mL}^{-1}$ for ABTS test) as shown in Figure 1. The deduced values of $\mathrm{IC}_{50}$ are presented in Table 4. A lower value of $\mathrm{IC}_{50}$ indicates a high antioxidant activity. Amphora sp. 80\% ethanolic extract exhibited high antiradical power with an $\mathrm{IC}_{50}$ value of $0.23 \pm 0.07 \mathrm{mg} \mathrm{mL}^{-1}$ for DPPH scavenging activity and an $\mathrm{IC}_{50}$ value of $2.61 \pm$ $0.64 \mathrm{mg} \mathrm{mL}^{-1}$ for ABTS radical scavenging capacity. Some authors have found a strong correlation between the phenolic contents and the antioxidant activity [41].

The FRAP assay is based on the ability of phenols to reduce yellow ferric tripyridyl triazine complex (Fe(III)TPTZ) to blue ferrous complex (Fe(II)-TPTZ) by the action of electron-donating antioxidants [42]. Figure 2(a) shows a significant reducing power compared to the vitamin $\mathrm{C}$ used as a reference. The reducing power was also dependent on the extract concentration.

The effect of antioxidants on DPPH free radical scavenging was considered to be emanating from their hydrogendonating ability. In this investigation, the $80 \%$ ethanol extract was proven to exhibit a strong effect of DPPH free radical scavenging. In fact, it reached $74.34 \%$ of inhibition at $1 \mathrm{mg}$ of extract, which is considered higher than the methanol extract of some Bacillariophyceae tested at $2 \mathrm{mg}$ of the extract $(22.7 \%$, $31.6 \%$, and $76.6 \%$ for Amphora coffeaeformis, Navicula sp., and Achnanthes longipes, resp.) [31]. The $\mathrm{IC}_{50}$ value for ABTS scavenging capacity of Amphora sp. extract was $2.6 \mathrm{mg} \mathrm{mL}^{-1}$. Many research studies [43] have mentioned $\mathrm{IC}_{50}$ ABTS scavenging capacities for two brown algae of $5.29 \mathrm{mg} \mathrm{mL}^{-1}$ for Sargassum binderi and $15.2 \mathrm{mg} \mathrm{mL}^{-1}$ for Turbinaria conoides.

The $\beta$-carotene bleaching inhibition and the reducing power tests (absorbance at $700 \mathrm{~nm}$ ) were measured at concentrations of extract between 0.1 and $0.5 \mathrm{mg} \mathrm{mL}^{-1}$, showing its dependency on concentration (Figure 2(b)). The $\mathrm{IC}_{50}$ value of $\beta$-carotene bleaching test (Table 4) was strong ( $0.21 \pm$ $0.05 \mathrm{mg} \mathrm{mL}^{-1}$ ), with about twice the $\mathrm{IC}_{50}$ value of vitamin $\mathrm{C}$ used as the standard. The absorbance at $700 \mathrm{~nm}$ reached a value of 0.78 at a concentration of $0.5 \mathrm{mg} \mathrm{mL}^{-1}$ of the extract, which is considered high, indicating a good antioxidant activity. Therefore, Amphora sp. extract was confirmed to have a strong antioxidant capacity. The multiple regression analysis has proven that both carotenoid and phenolic 
TABLE 3: Extraction yields and polyphenols and flavonoids contents in extracts from Amphora sp. with different solvents.

\begin{tabular}{lccc}
\hline Solvent & Yield (\% DW) & Polyphenols $\left(\mathrm{mg} \mathrm{GAE} \mathrm{g}^{-1}\right.$ extract) & ${\text { Flavonoids }\left(\mathrm{mg} \mathrm{CE} \mathrm{g}^{-1} \text { extract) }\right.}$ \\
\hline $80 \%$ ethanol & $18.20 \pm 0.21$ & $38.27 \pm 2.21$ & $17.69 \pm 0.70$ \\
Hexane & $14.95 \pm 0.25$ & $11.47 \pm 0.60$ & $4.76 \pm 0.15$ \\
Ethyl acetate & $2.78 \pm 0.12$ & $14.04 \pm 0.31$ & $5.25 \pm 0.30$ \\
Water & $23.61 \pm 0.30$ & $13.34 \pm 0.24$ & $4.27 \pm 0.20$ \\
\hline
\end{tabular}

Data are expressed as mean \pm standard deviation of triplicates. GAE: gallic acid equivalent; CE: catechin equivalent.

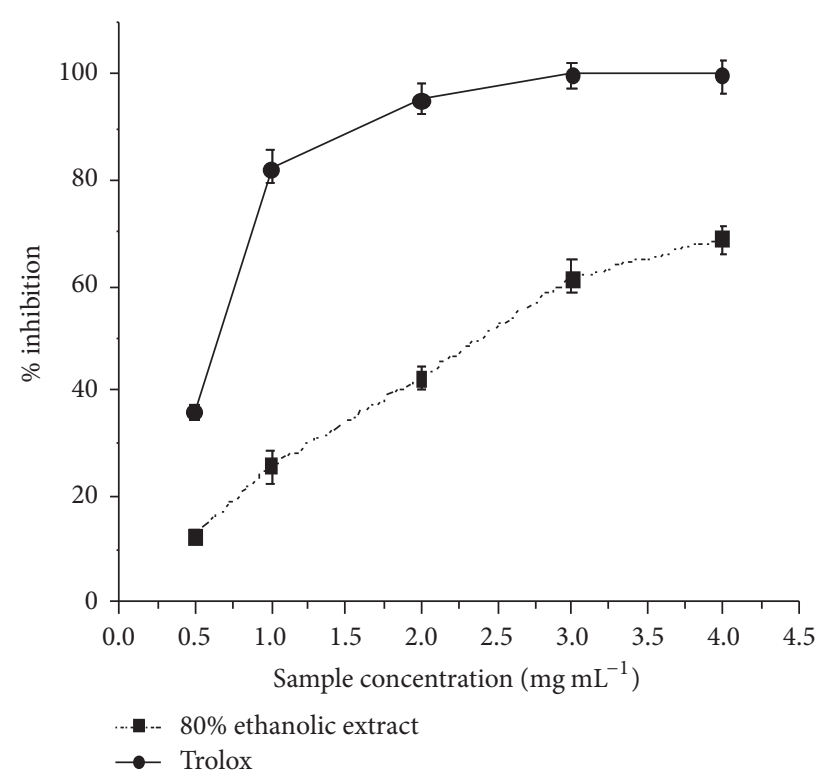

(a)

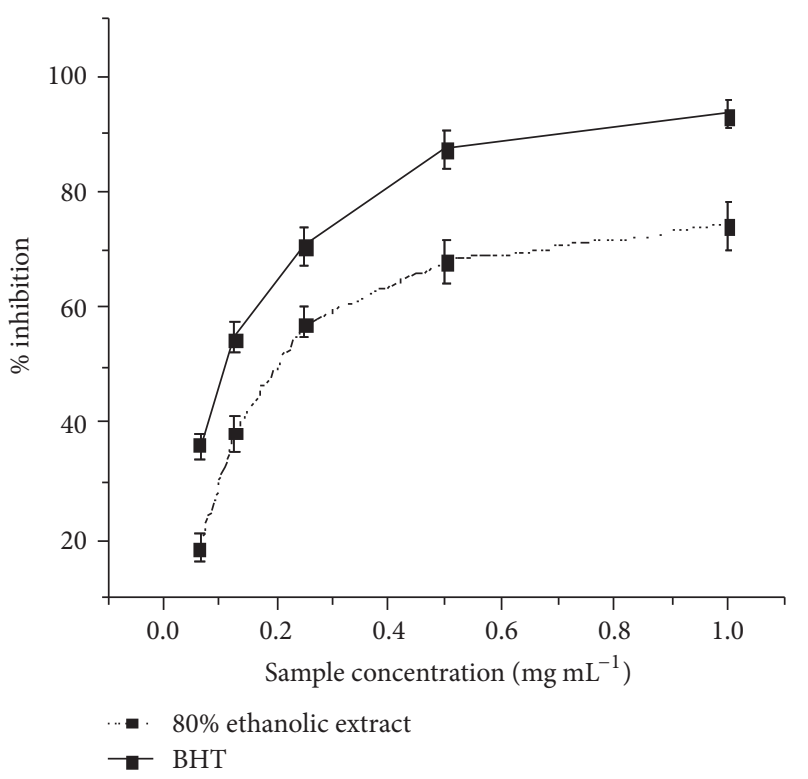

(b)

FIGURE 1: Anti-free radical effects of Amphora sp. 80\% ethanolic extract for ABTS (a) and DPPH (b) compared to respective standards (Trolox and BHT).

TABLE 4: $\mathrm{IC}_{50}$ values for antioxidant capacities of Amphora sp. extract compared to standards.

\begin{tabular}{lcc}
\hline Activity & Extract $\left(\mathrm{mg} \mathrm{mL}^{-1}\right)$ & Standard \\
\hline DPPH radical scavenging activity & $0.23 \pm 0.07$ & $0.11 \pm 0.03$ \\
ABTS radical scavenging activity & $2.61 \pm 0.64$ & $0.54 \pm 0.08$ \\
$\beta$-Carotene bleaching assay & $0.21 \pm 0.05$ & $0.09 \pm 0.01$ \\
\hline
\end{tabular}

Data are expressed as mean \pm standard deviation of triplicates.

contents significantly contribute to the explanation of the variation in FRAP and TEAC activity of the extracts. The regression coefficients indicate that phenols and carotenoids are of similar importance in explaining variation in the antioxidant activity [25].

3.5. Antibacterial Assay. In the present study, the antibacterial activity of Amphora sp. $80 \%$ ethanolic extract was screened against six bacteria and their potency was qualitatively and quantitatively analyzed by the diameters of the inhibition zones (IZD) as summarized in Table 5. The $80 \%$ ethanolic extract of Amphora sp., at a concentration of $20 \mathrm{mg} \mathrm{mL}^{-1}$, was active against Gram-positive bacteria, Micrococcus luteus and Staphylococcus aureus, and inactive against both strains of Bacillus (cereus and subtilis). This extract was active against Gram-negative bacteria tested: Klebsiella pneumonia and Salmonella enterica. The extract exhibited strong activity against Micrococcus luteus, Staphylococcus aureus, and Klebsiella pneumoniae. The IZD for Klebsiella pneumoniae and Staphylococcus aureus of $16 \mathrm{~mm}$ and $20 \mathrm{~mm}$, respectively, were stronger than those found for the ethanolic extract of a strain of Amphora sp. cultured in standard Walne's medium $(10 \mathrm{~mm}$ and $10.5 \mathrm{~mm})$, respectively [44]. This difference may be due to the culture conditions. According to some authors, the antimicrobial activity of algae depends on the species and the extraction efficiency of the active compounds as well as survival conditions [45].

The extract used in this study was found to be rich in a variety of compounds: lipids and fatty acids, carbohydrates, polysaccharides, polyphenols, flavonoids, pigments, and carotenoids, which can be indicative for having antibacterial activity as mentioned for several microalgae [46]. The antimicrobial activity of microalgae has been attributed to compounds belonging to several chemical classes including indoles, terpenes, acetogenins, phenols, fatty acids, and volatile halogenated hydrocarbons [47, 48]. The mechanisms of action of some antimicrobial agents were described; carotenoids digest the cell wall [49]; flavonoids 
TABLE 5: Antibacterial activity of Amphora sp. 80\% ethanolic extract.

\begin{tabular}{|c|c|c|}
\hline \multirow{2}{*}{ Strains } & \multirow{2}{*}{ Gram +/- } & $\mathrm{IZD}(\mathrm{mm})$ \\
\hline & & $80 \%$ ethanol extract of Amphora sp. \\
\hline Bacillus cereus (ATCC11778) & + & $0 \pm 0$ \\
\hline Bacillus subtilis (JN934392) & + & $0 \pm 0$ \\
\hline Micrococcus luteus (ATCC4698) & + & $16 \pm 0.5$ \\
\hline Staphylococcus aureus (ATCC6538) & + & $20 \pm 2$ \\
\hline Klebsiella pneumoniae (ATCC13883) & - & $16 \pm 0.5$ \\
\hline Salmonella enterica (ATCC43972) & - & $12 \pm 1$ \\
\hline
\end{tabular}

The data are expressed as mean $\pm \mathrm{SD}(n=3)$. IZD: inhibition zone diameter.

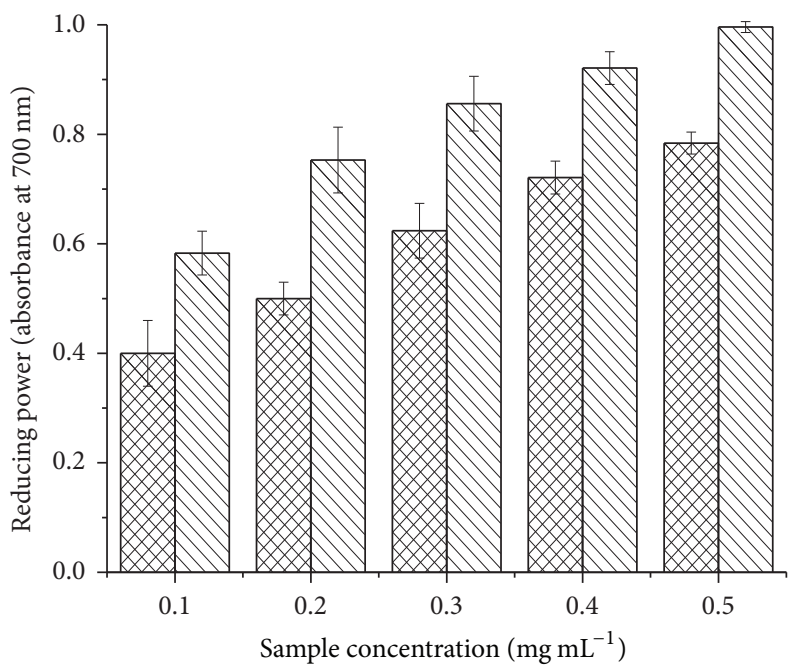

$80 \%$ ethanolic extract

MV Vit C

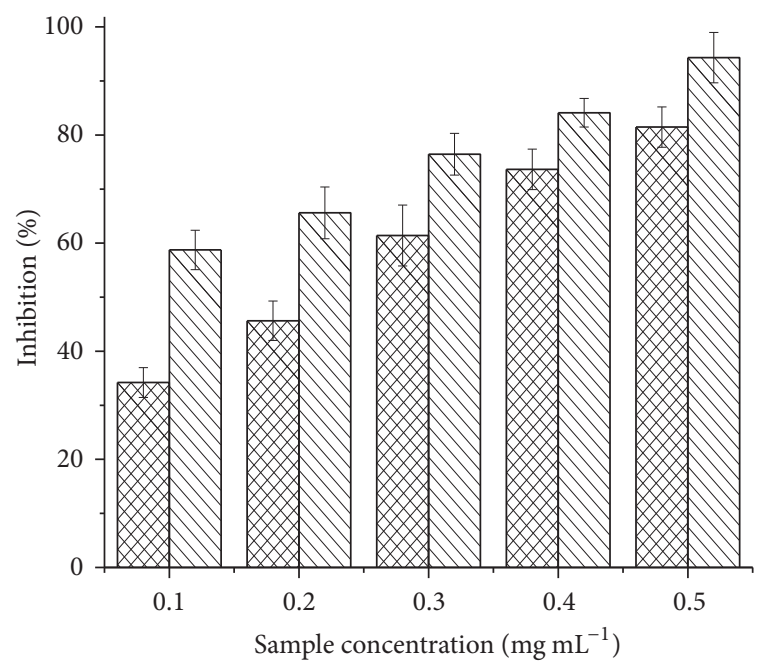

$80 \%$ ethanolic extract

MIV Vit C

(a)

(b)

FIGURE 2: Ferric reducing antioxidant power (FRAP) (a) and beta-carotene bleaching test (b) for $80 \%$ ethanolic extract of Amphora sp. compared to vitamin $\mathrm{C}$ (Vit C) as a standard.

increase permeability of the inner bacteria [50]; polyphenols participate in enzyme inhibition, substrate deprivation, complexing with cell wall, and membrane disruption [8]; polysaccharides inhibit hyaluronidase [8], while fatty acids and lipids cause the disruption of the cellular membrane [51]. The antimicrobial activity of supercritical extracts obtained from the microalga Chaetoceros muelleri was related to its lipids composition [52]. Fatty acids were reported to be bioactive compounds having antibacterial activity in some diatoms Phaeodactylum tricornutum $[51,53]$ and Skeletonema costatum [54] and other microalgae Haematococcus pluvialis [55] and Dunaliella salina [56].

Microalgae extracts should be tested as additives for food and feed formulations, in an attempt to replace the currently used antimicrobial compounds of synthetic origins, including subtherapeutical doses of antibiotics employed as a prophylactic measure in animal breeding [9].

\section{Conclusion}

Amphora sp., a brown microalga cultivated in high salinity medium of 100 p.s.u., was confirmed to contain a moderate percentage of proteins, lipids, sugars, and minerals and important levels of polyphenols, flavonoids, chlorophyll, carotenoids, and bioactive fatty acids as EPA. Besides, this microalga has important antioxidant and antibacterial activities. Prominent contents of bioactive compounds in this microalga are in favor of its possible valorization in food additives and pharmaceutical or cosmetic products. Moreover, its richness in saturated fatty acids allows its eventual use for biodiesel production.

\section{Conflicts of Interest}

The authors declare no conflicts of interest regarding the publication of this paper. 


\section{Authors' Contributions}

Saoussan Boukhris and Khaled Athmouni contributed equally to this work.

\section{Acknowledgments}

This work was supported by the Ministry of Higher Education and Scientific Research, Tunisia. The authors would like to thank Professor Noureddine Drira from the Sfax Faculty of Sciences for the availability of the culture chamber and the laminar flow hood to the maintenance of microalga cultures. They would also like to thank Professor Neji Garsallallah and Dr. Sabrine Sellimi for their help.

\section{References}

[1] G. N. Gupta, S. K. Tiwari, K. Lawrence, and R. S. Lawrence, "Effect of silicon on growth and biodiesel production in fresh water diatoms," Plant Archives, vol. 11, no. 2, pp. 673-676, 2011.

[2] J. M. Graham, L. E. Graham, S. B. Zulkifly, B. F. Pfleger, S. W. Hoover, and J. Yoshitani, "Freshwater diatoms as a source of lipids for biofuels," Journal of Industrial Microbiology \& Biotechnology, vol. 39, no. 3, pp. 419-428, 2012.

[3] A. Affan, R. Karawita, Y.-J. Jeon, B.-Y. Kim, and J.-B. Lee, "Growth characteristics, bio-chemical composition and antioxidant activities of benthic diatom grammatophora marina from jeju coast, korea," Algae, vol. 21, no. 1, pp. 141-148, 2006.

[4] R. Karawita, M. Senevirathne, Y. Athukorala et al., "Protective effect of enzymatic extracts from microalgae against DNA damage induced by $\mathrm{H}_{2} \mathrm{O}_{2}$," Marine Biotechnology, vol. 9, no. 4, pp. 479-490, 2007.

[5] S.-H. Lee, R. Karawita, A. Affan, J.-B. Lee, B.-J. Lee, and Y.-J. Jeon, "Potential antioxidant activites of enzymatic digests from benthic diatoms Achnanthes longipes, Amphora coffeaeformis, and Navicula sp. (Bacillariophyceae)," Journal of Food Science and Nutrition, vol. 13, no. 3, pp. 166-175, 2008.

[6] C. Bonnineau, I. G. Sague, G. Urrea, and H. Guasch, "Light history modulates antioxidant and photosynthetic responses of biofilms to both natural (light) and chemical (herbicides) stressors," Ecotoxicology, vol. 21, no. 4, pp. 1208-1224, 2012.

[7] A. C. Guedes, H. M. Amaro, and F. X. Malcata, "Microalgae as sources of high added-value compounds-a brief review of recent work," Biotechnology Progress, vol. 27, no. 3, pp. 597-613, 2011.

[8] H. M. Amaro, A. C. Guedes, and F. X. Malcata, "Antimicrobial activities of microalgae: an invited review," Science against Microbial Pathogens: Communicating Current Research And Technological Advances, vol. 3, 2011.

[9] J. Tramper, C. Battershill, W. Brandenburg et al., "What to do in marine biotechnology?" Biomolecular Engineering, vol. 20, no. 4-6, pp. 467-471, 2003.

[10] E. Christaki, E. Bonos, I. Giannenas, and P. Florou-Paneria, "Functional properties of carotenoids originating from algae," Journal of the Science of Food and Agriculture, vol. 93, no. 1, pp. 5-11, 2013.

[11] A. Aullón Alcaine, Biodiesel from microalgae [Doctoral dissertation], Universitat Politècnica de Catalunya. Escola Universitària d'Enginyeria Tècnica Industrial d'Igualada (ET Industrial, especialitat en Química Industrial), 2010.
[12] S. Scala and C. Bowler, "Molecular insights into the novel aspects of diatom biology," Cellular and Molecular Life Sciences, vol. 58, no. 11, pp. 1666-1673, 2001.

[13] S. Masmoudi, E. Tastard, W. Guermazi, A. Caruso, A. MorantManceau, and H. Ayadi, "Salinity gradient and nutrients as major structuring factors of the phytoplankton communities in salt marshes," Aquatic Ecology, 2015.

[14] R. P. F. F. da Silva, T. A. P. Rocha-Santos, and A. C. Duarte, "Supercritical fluid extraction of bioactive compounds," TrACTrends in Analytical Chemistry, vol. 76, pp. 40-51, 2016.

[15] K. Bone and S. Mills, Principles and Practice of Phytotherapy. Modern Herbal Medicine, Elsevier Limitd, 2013.

[16] H. Ayadi, O. Abid, J. Elloumi, A. Bouaïn, and T. Sime-Ngando, "Structure of the phytoplankton communities in two lagoons of different salinity in the Sfax saltern (Tunisia)," Journal of Plankton Research, vol. 26, no. 6, pp. 669-679, 2004.

[17] R. R. Guillard and J. H. Ryther, "Studies of marine planktonic diatoms. I. Cyclotella nana Hustedt, and Detonula confervacea (CLEVE) Gran," Canadian Journal of Microbiology, vol. 8, pp. 229-239, 1962.

[18] R. R. Guillard, "Culture of phytoplankton for feeding marine invertebrates," in Culture of Marine Invertebrate Animals, animals. and of. Culture marine invertebrate animals, Eds., pp. 2960, Springer, 1975.

[19] W. Horwitz, "Official methods of analysis of AOAC International," in Proceeding of the AOAC International, Gaithersburg, Md., Gaithersburg, Md, 2000.

[20] M. DuBois, K. A. Gilles, J. K. Hamilton, P. A. Rebers, and F. Smith, "Colorimetric method for determination of sugars and related substances," Analytical Chemistry, vol. 28, no. 3, pp. 350356, 1956.

[21] H. K. Lichtenthaler, "Chlorophylls and carotenoids: Pigments of photosynthetic biomembranes," in Methods in Enzymology, vol. 148, pp. 350-382, 1987.

[22] Association of Official Analytical, Official methods of analysis of AOAC International, edited by P. Cunniff, Washington, D.C..

[23] C.-C. Chang, M.-H. Yang, H.-M. Wen, and J.-C. Chern, "Estimation of total flavonoid content in propolis by two complementary colorimetric methods," Journal of Food and Drug Analysis, vol. 10, no. 3, pp. 178-182, 2002.

[24] J. Zhishen, T. Mengcheng, and W. Jianming, “The determination of flavonoid contents in mulberry and their scavenging effects on superoxide radicals," Food Chemistry, vol. 64, no. 4, pp. 555$559,1999$.

[25] K. Goiris, K. Muylaert, I. Fraeye, I. Foubert, J. De Brabanter, and L. De Cooman, "Antioxidant potential of microalgae in relation to their phenolic and carotenoid content," Journal of Applied Phycology, vol. 24, no. 6, pp. 1477-1486, 2012.

[26] M. S. Blois, "Antioxidant determinations by the use of a stable free radical," Nature, vol. 181, no. 4617, pp. 1199-1200, 1958.

[27] V. Katalinic, D. Modun, I. Music, and M. Boban, "Gender differences in antioxidant capacity of rat tissues determined by 2, 2'-azinobis (3-ethylbenzothiazoline 6-sulfonate; ABTS) and ferric reducing antioxidant power (FRAP) assays," Comparative Biochemistry and Physiology Part C: Toxicology Pharmacology, vol. 140, no. 1, pp. 47-52, 2005.

[28] A. Yıldırım, A. Mavi, and A. A. Kara, "Determination of anti-oxidant and antimicrobial activities of Rumex crispus L. 
extracts," Journal of Agricultural and Food Chemistry, vol. 49, no. 8, pp. 4083-4089, 2001.

[29] I. I. Koleva, T. A. van Beek, J. P. H. Linssen, A. de Groot, and L. N. Evstatieva, "Screening of plant extracts for antioxidant activity: a comparative study on three testing methods," Phytochemical Analysis, vol. 13, no. 1, pp. 8-17, 2002.

[30] H. Chtourou, I. Dahmen, A. Jebali et al., "Characterization of Amphora sp., a newly isolated diatom wild strain, potentially usable for biodiesel production," Bioprocess and Biosystems Engineering, vol. 38, no. 7, pp. 1381-1392, 2015.

[31] S.-H. Lee, R. Karawita, A. Affan et al., "Potential of benthic diatoms Achnanthes longipes, Amphora coffeaeformis and Navicula sp. (Bacillariophyceae) as Antioxidant Sources," Algae, vol. 24, no. 1, pp. 47-55, 2009.

[32] H. Khatoon, S. Banerjee, F. M. Yusoff, and M. Shariff, "Evaluation of indigenous marine periphytic Amphora, Navicula and Cymbella grown on substrate as feed supplement in Penaeus monodon postlarval hatchery system," Aquaculture Nutrition, vol. 15, no. 2, pp. 186-193, 2009.

[33] L. Ying, M. Kang-Sen, and S. Shi-Chun, "Total lipid and fatty acid composition of eight strains of marine diatoms," Chinese Journal of Oceanology and Limnology, vol. 18, no. 4, pp. 345-349, 2000.

[34] M. R. Brown, "The amino-acid and sugar composition of 16 species of microalgae used in mariculture," Journal of Experimental Marine Biology and Ecology, vol. 145, no. 1, pp. 79-99, 1991.

[35] P. Kuczynska, M. Jemiola-Rzeminska, and K. Strzalka, "Photosynthetic pigments in diatoms," Marine Drugs, vol. 13, no. 9, pp. 5847-5881, 2015.

[36] C. F. Gao, Y. Zhai, Y. Ding, and Q. Wu, "Application of sweet sorghum for biodiesel production by heterotrophic microalga Chlorella protothecoides," Applied Energy, vol. 87, no. 3, pp. 756761, 2010.

[37] A. P. Desbois, M. Walton, and V. J. Smith, "Differential antibacterial activities of fusiform and oval morphotypes of Phaeodactylum tricornutum (Bacillariophyceae)," Journal of the Marine Biological Association of the United Kingdom, vol. 90, no. 4, pp. 769-774, 2010.

[38] I. Iglesia, I. Huybrechts, M. González-Gross et al., "Folate and vitamin B 12 concentrations are associated with plasma DHA and EPA fatty acids in European adolescents: the Healthy Lifestyle in Europe by Nutrition in Adolescence (HELENA) study," British Journal of Nutrition, vol. 117, no. 01, pp. 124-133, 2017.

[39] W. Zheng, X. Wang, W. Cao et al., "E-configuration structures of EPA and DHA derived from Euphausia superba and their significant inhibitive effects on growth of human cancer cell lines," Leukotrienes and Essential Fatty Acids (PLEFA), vol. 117, pp. 47-53, 2017.

[40] A. Maadane, N. Merghoub, T. Ainane et al., "Antioxidant activity of some Moroccan marine microalgae: pufa profiles, carotenoids and phenolic content," Journal of Biotechnology, vol. 215, pp. 13-19, 2015.

[41] K. Athmouni, T. Belghith, K. Bellassouad, A. E. Feki, and H. Ayadi, "Effect of extraction solvents on the biomolecules and antioxidant properties of Scorzonera undulata (Asteraceae): application of factorial design optimization phenolic extraction," Acta Scientiarum Polonorum, Technologia Alimentaria, vol. 14, no. 4, pp. 313-320, 2015.
[42] I. F. F. Benzie and J. J. Strain, "The ferric reducing ability of plasma (FRAP) as a measure of 'antioxidant power': the FRAP assay," Analytical Biochemistry, vol. 239, no. 1, pp. 70-76, 1996.

[43] W. Boonchum, Y. Peerapornpisal, D. Kanjanapothi et al., "Antioxidant activity of some seaweed from the Gulf of Thailand," International Journal of Agriculture and Biology, vol. 13, no. 1, pp. 95-99, 2011.

[44] R. M. Appavoo and D. G. Femi, "Eurihaline microalgae-a novel substance against post operative pathogen," International Journal of Development Research, vol. 5, no. 1, pp. 3030-3033, 2015.

[45] R. Lavanya and N. Veerappan, "Antibacterial potential of six seaweeds collected from Gulf of Mannar of southeast coast of India," Advances in Biological Research, vol. 5, no. 1, pp. 38-44, 2011.

[46] J. Pradhan, S. Das, and B. K. Das, "Antibacterial activity of freshwater microalgae: a review," African Journal of Pharmacy and Pharmacology, vol. 8, no. 32, pp. 809-818, 2014.

[47] A. M. Mayer and M. T. Hamann, "Marine pharmacology in 2001-2002: marine compounds with anthelmintic, antibacterial, anticoagulant, antidiabetic, antifungal, anti-inflammatory, antimalarial, antiplatelet, antiprotozoal, antituberculosis, and antiviral activities; affecting the cardiovascular, immune and nervous systems and other miscellaneous mechanisms of action," Comparative Biochemistry and Physiology Part C: Toxicology Pharmacology, vol. 140, no. 3-4, pp. 265-286, 2005.

[48] K. H. Cardozo, T. Guaratini, M. P. Barros et al., "Metabolites from algae with economical impact," Comparative Biochemistry and Physiology Part C: Toxicology Pharmacology, vol. 146, no. 1, pp. 60-78, 2007.

[49] M. Cucco, B. Guasco, G. Malacarne, and R. Ottonelli, "Effects of $\beta$-carotene on adult immune condition and antibacterial activity in the eggs of the Grey Partridge," Comparative Biochemistry and Physiology Part A: Molecular and Integrative Physiology, vol. 147, no. 4, pp. 1038-1046, 2007.

[50] O. K. Mirzoeva, R. N. Grishanin, and P. C. Calder, "Antimicrobial action of propolis and some of its components: the effects on growth, membrane potential and motility of bacteria," Microbiological Research, vol. 152, no. 3, pp. 239-246, 1997.

[51] A. P. Desbois, A. Mearns-Spragg, and V. J. Smith, "A fatty acid from the diatom Phaeodactylum tricornutum is antibacterial against diverse bacteria including multi-resistant Staphylococcus aureus (MRSA)," Marine Biotechnology, vol. 11, no. 1, pp. 45$52,2009$.

[52] J. A. Mendiola, C. F. Torres, A. Toré et al., "Use of supercritical $\mathrm{CO}_{2}$ to obtain extracts with antimicrobial activity from Chaetoceros muelleri microalga. A correlation with their lipidic content," European Food Research and Technology, vol. 224, no. 4, pp. 505-510, 2007.

[53] V. J. Smith, A. P. Desbois, and E. A. Dyrynda, "Conventional and unconventional antimicrobials from fish, marine invertebrates and micro-algae," Marine Drugs, vol. 8, no. 4, pp. 1213-1262, 2010.

[54] M. Naviner, J.-P. Bergé, P. Durand, and H. Le Bris, “Antibacterial activity of the marine diatom Skeletonema costatum against aquacultural pathogens," Aquaculture, vol. 174, no. 1-2, pp. 1524, 1999.

[55] S. Santoyo, I. Rodríguez-Meizoso, A. Cifuentes et al., "Green processes based on the extraction with pressurized fluids to 
obtain potent antimicrobials from Haematococcus pluvialis microalgae," LWT-Food Science and Technology, vol. 42, no. 7, pp. 1213-1218, 2009.

[56] M. Herrero, E. Ibáñez, A. Cifuentes, G. Reglero, and S. Santoyo, "Dunaliella salina microalga pressurized liquid extracts as potential antimicrobials," Journal of Food Protection, vol. 69, no. 10, pp. 2471-2477, 2006. 

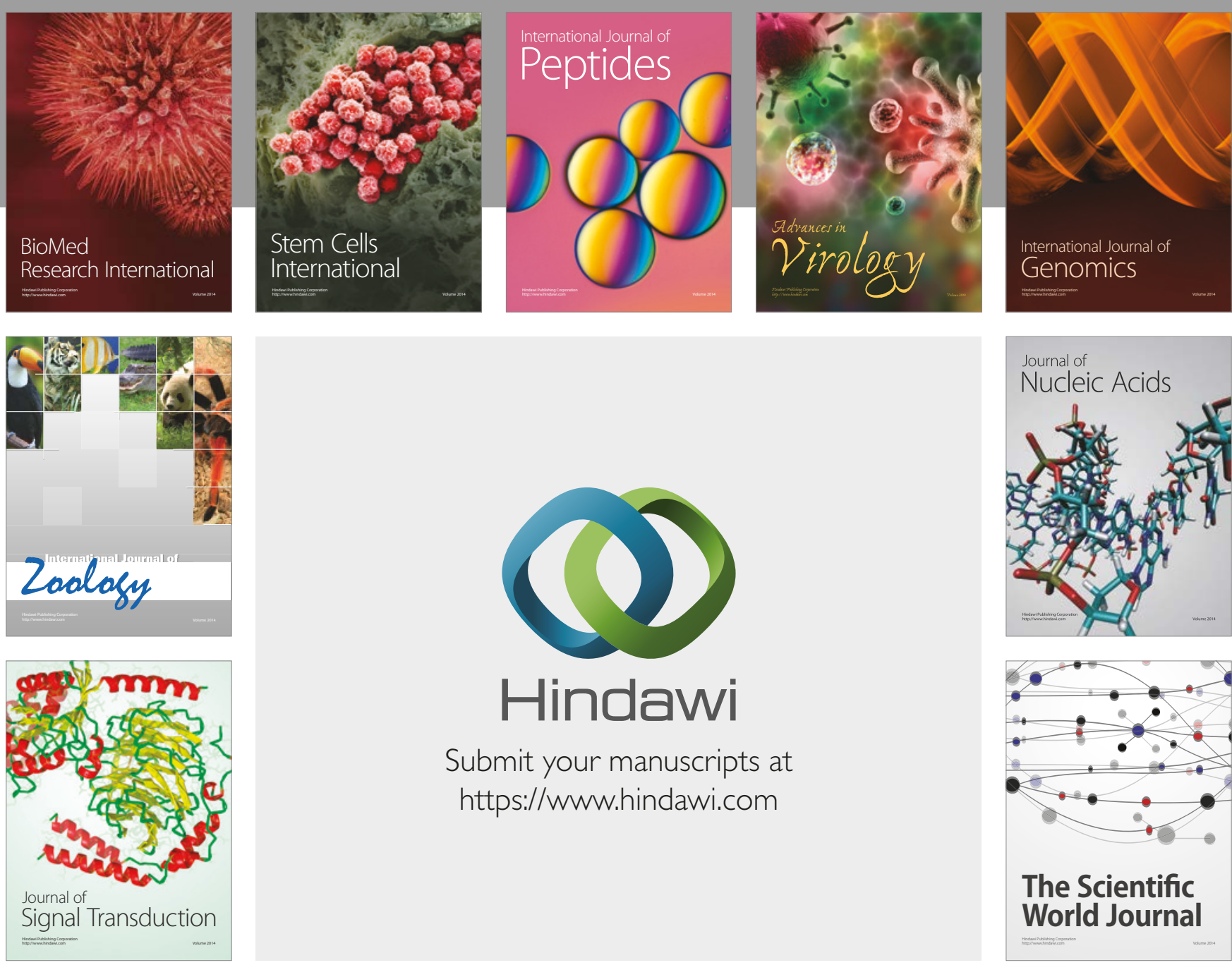

Submit your manuscripts at

https://www.hindawi.com
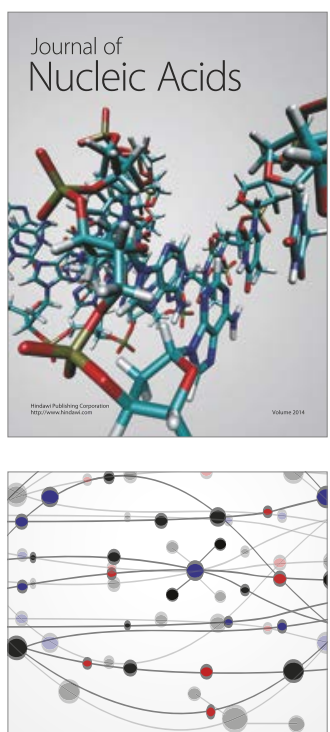

The Scientific World Journal

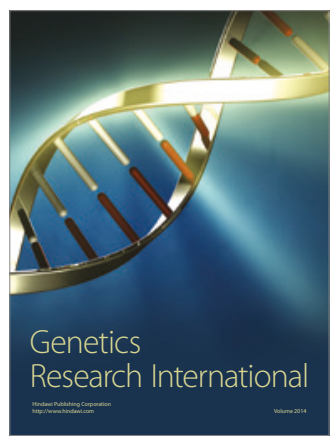

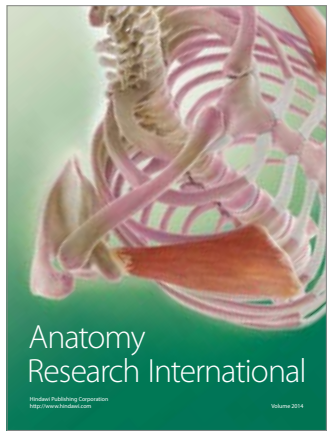

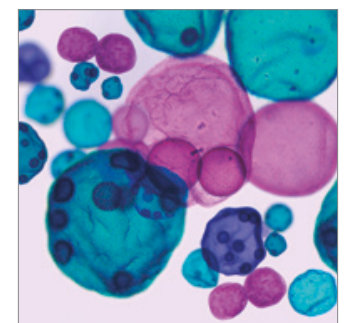

International Journal of Microbiology
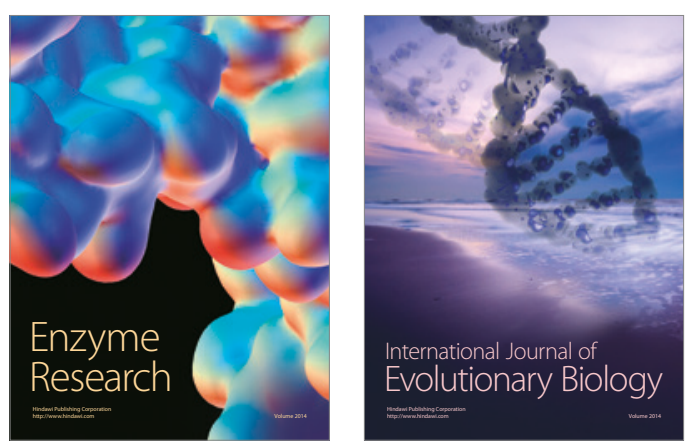
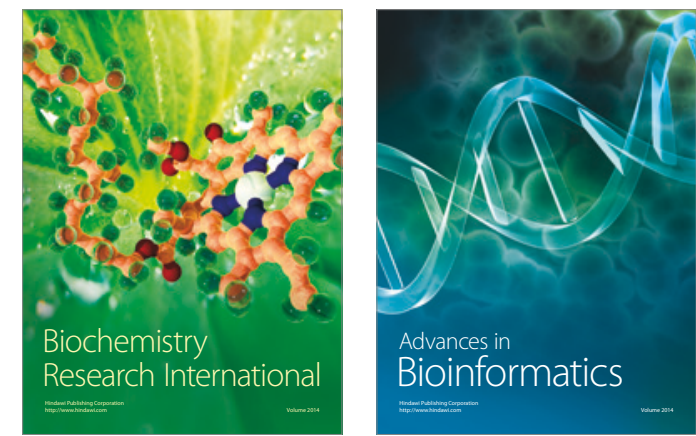

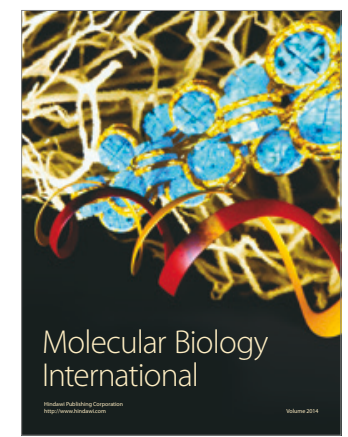

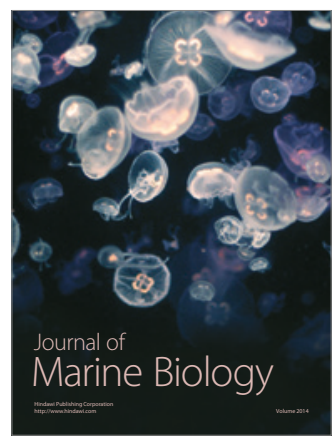

